\title{
24. PALYNOLOGY OF PALEOCENE SEDIMENTS AT SITE 214, NINETYEAST RIDGE
}

\author{
Wayne K. Harris, Geological Survey of South Australia, Department of Mines, Adelaide, South Australia
}

\begin{abstract}
DSDP Site 214 , situated at about $11^{\circ} \mathrm{S}$ on the Ninetyeast Ridge in the Indian Ocean, penetrated a sequence of carbonaceous to lignitic clays and sands interbedded with volcanoclastics between 340 and 500 meters. Palynological evidence, spores, pollen, and dinoflagellate cysts, indicates a Paleocene age for this part of the sequence, and correlation is within the Australasian region rather than the tropics of Africa, South America, India or Southeast Asia. Below about 390 meters the sequence is entirely nonmarine. Above this, marine influence is dominant.

The microflora indicates a temperate climate of high rainfall not dissimilar to present climates of southeast Australia or New Zealand. But the assemblage is restricted in that many characteristic species and genera (e.g., Proteacidites) of Australasian early Tertiary rocks are absent and the flora must have been oceanic-island in aspect with no direct contact with continental masses.

It is suggested that the northern part of the Ninetyeast Ridge was in temperate regions during the Paleocene and moved northwards after the separation of the Australian and Antarctic plates. There is no palynological evidence to support a connection of this part of the ridge with either India or Southeast Asia.
\end{abstract}

\section{INTRODUCTION}

Deep-sea drilling projects do not often provide the palynologist with a wealth of palynological data, but Site 214 , in penetrating a sequence of carbonaceous clays and sands interbedded with volcanic flows, presented a unique opportunity to not only date biostratigraphically the sequence but also test current theories related to plate tectonics and Southern Hemisphere biogeography.

Site 214 of DSDP Leg 22 was sited on the north-south trending Ninetyeast Ridge (see Figure 1) at lat $11^{\circ} 20.2^{\prime} \mathrm{S}$, long. $88^{\circ} 43.1^{\prime} \mathrm{E}$ and 1665 meters of water. At a subbottom depth between 390 and 500 meters, a sequence of volcanic rocks and interbedded carbonaceous clays and sands was recovered. For about 50 meters above this interval, sediments were glauconitic and calcareous silts which are also slightly carbonaceous.

This report details the palynology of the shallow-water marine and the nonmarine sequences. The distribution and frequency of species are summarized in Figure 2 and the samples studied are listed in Table 1. Large sampling gaps, particularly in the lower part of the sequence, are due mainly to unfavorable lithologies, in particular, volcanoclastics. All samples have been prepared in a manner similar to that outlined by Harris (1971). The technique is a standard hydrofluoric acid digestion followed by oxidation with Schultze solution and removal of humic acids with potassium carbonate. Calcareous sediments were pretreated with dilute hydrochloric acid. Slides and residues are housed in the Palynological Collection of the Geological Survey of South Australia. Examination of specimens is by transmitted light with phase contrast and Nomarski differential interference contrast using a Leitz Orthoplan microscope (No. 715494) in the above institution. All coordinates of species illustrated in the Plates are from this microscope.

\section{RESULTS}

The distribution and relative frequency of species is plotted on Figure 2. Counts on samples in the nonmarine sequence are based on 200 specimens, and because of low yields in the marine section, counts, where possible, were based on only 100 specimens. These low counts, nevertheless, show important trends.

Most species are illustrated in the accompanying plates and the detailed systematics of these will be treated elsewhere. Thus an "open" nomenclature has been adopted for the majority of species.

Samples S2506, S2507, S2499, and S2495 from Cores 52 and 53 were barren, probably due to baking by volcanic flows. The topmost sample, S2504, 'from Core 36 was also barren, but this is due to either unfavorable conditions during deposition or post-depositional oxidation. Most samples yielded abundant and well-preserved palynomorphs.

Qualitatively, the assemblages show little or no change upsection apart from the introduction of marine species. Thus, there is no evidence of any major microfloral changes in the assemblages, and they can be treated as essentially the one unit. The appearance of Areoligera sp. in high 


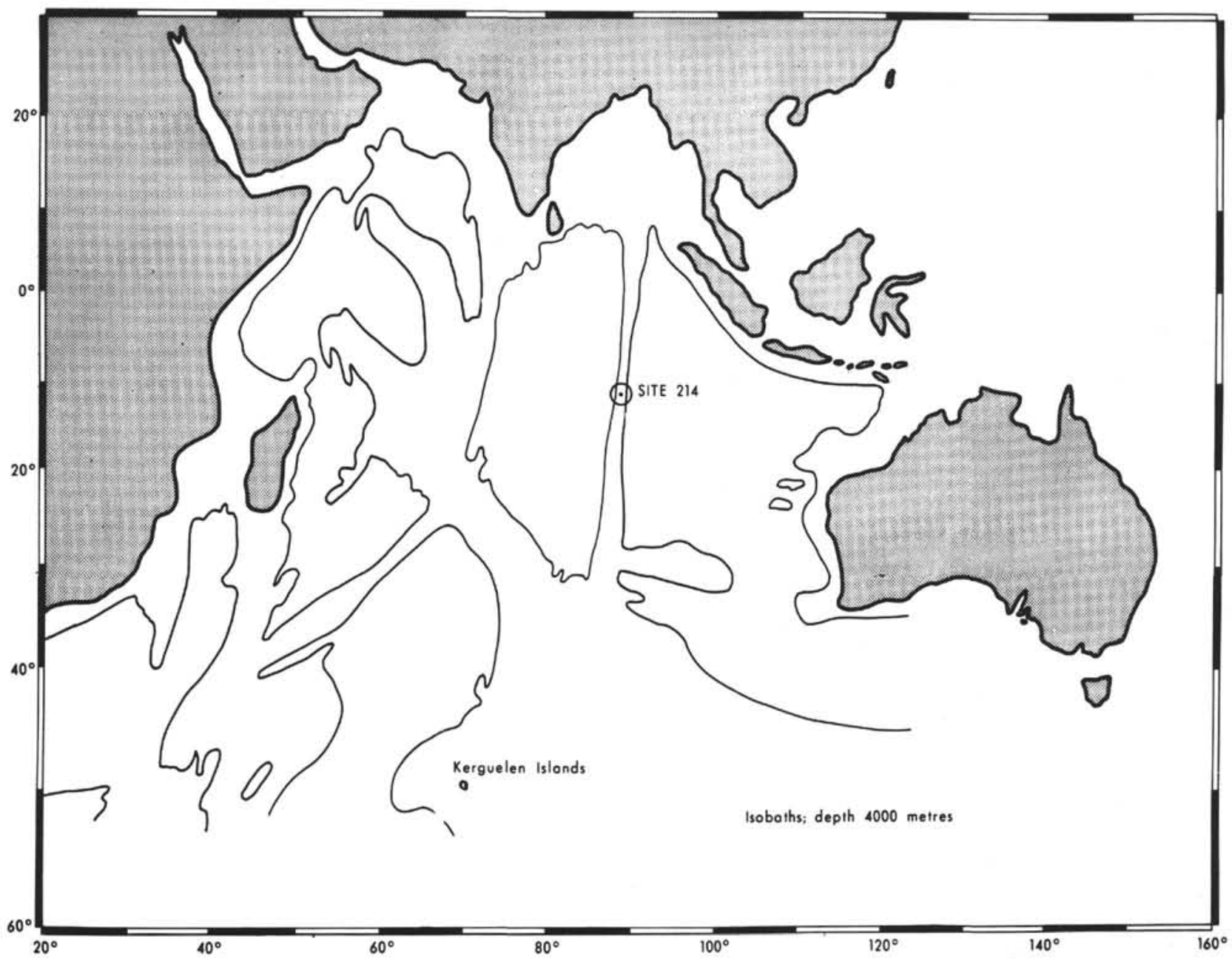

Figure 1. Location of Site 214, Indian Ocean.

frequencies towards the top of the section studied may be of biostratigraphic significance or merely a biofacies.

Quantitatively, the terrestrial components show regression and progression of paludal environments in that dominance of pteridophyte over gymnosperm and angiosperm species indicates local swamp conditions. The most significant assemblage of this type occurs at 403.68 meters. At or about 389.50 meters, the onset of marine influence is strongly marked by abundant dinoflagellate cysts ( $54 \%$ of the palynomorph assemblage), and these continue to increase in dominance to the almost exclusion of terrestrial components (3\% at $343 \mathrm{~m}$ ). The position of the core catcher sample from Core 41 is placed at the bottom of the 9 meter core, but it could have come from higher in that core. Similarly, other core catcher samples are taken as being from the bottom of their respective cores. Thus, there would be a maximum of about 10 meters between the core catcher sample from Core 41 and the best located sample from Core 42, Section 1.

\section{BIOSTRATIGRAPHY, CORRELATION AND AGE}

The assemblages are distinctly Australasian, and, although they are not as diverse as early Tertiary microfloras from either southern Australia or New Zealand, they can be compared and correlated with them. Couper (1960), Dettmann and Playford (1969), Harris (1965a, 1971), Stover and Evans (in press) and Stover and Partridge (in press) have provided biostratigraphic schemes for the Late Cretaceous and early Tertiary in these regions.

The species that are of correlative value and their stratigraphic ranges in Australian and New Zealand are as follows:

Australopollis obscurus (Harris): Appendicisporites distocarinatus Zone (Cenomanian-Turonian) (Dettmann and Playford, 1969) to Gambierina edwardsii Zone (middle to Late Paleocene) (Harris, 1971; Stover and Partridge, in press).

Clavatipollenites sp.: Paleocene, Australia (author's unpublished data) and as Ascarina sp. Paleocene to Recent, New Zealand (Couper, 1960).

Haloragacidites harrisii (Couper): Lygistepollenites balmei Zone (middle Paleocene) through late Tertiary (Stover and Partridge, in press).

Krauselisporites papillatus Harris: Gambierina edwardsii Zone (middle Paleocene) through middle Eocene (author's unpublished data).

Microfoveolatosporites fromensis (Cookson): Gambierina edwardsii Zone (Harris, 1965a and unpublished data). 


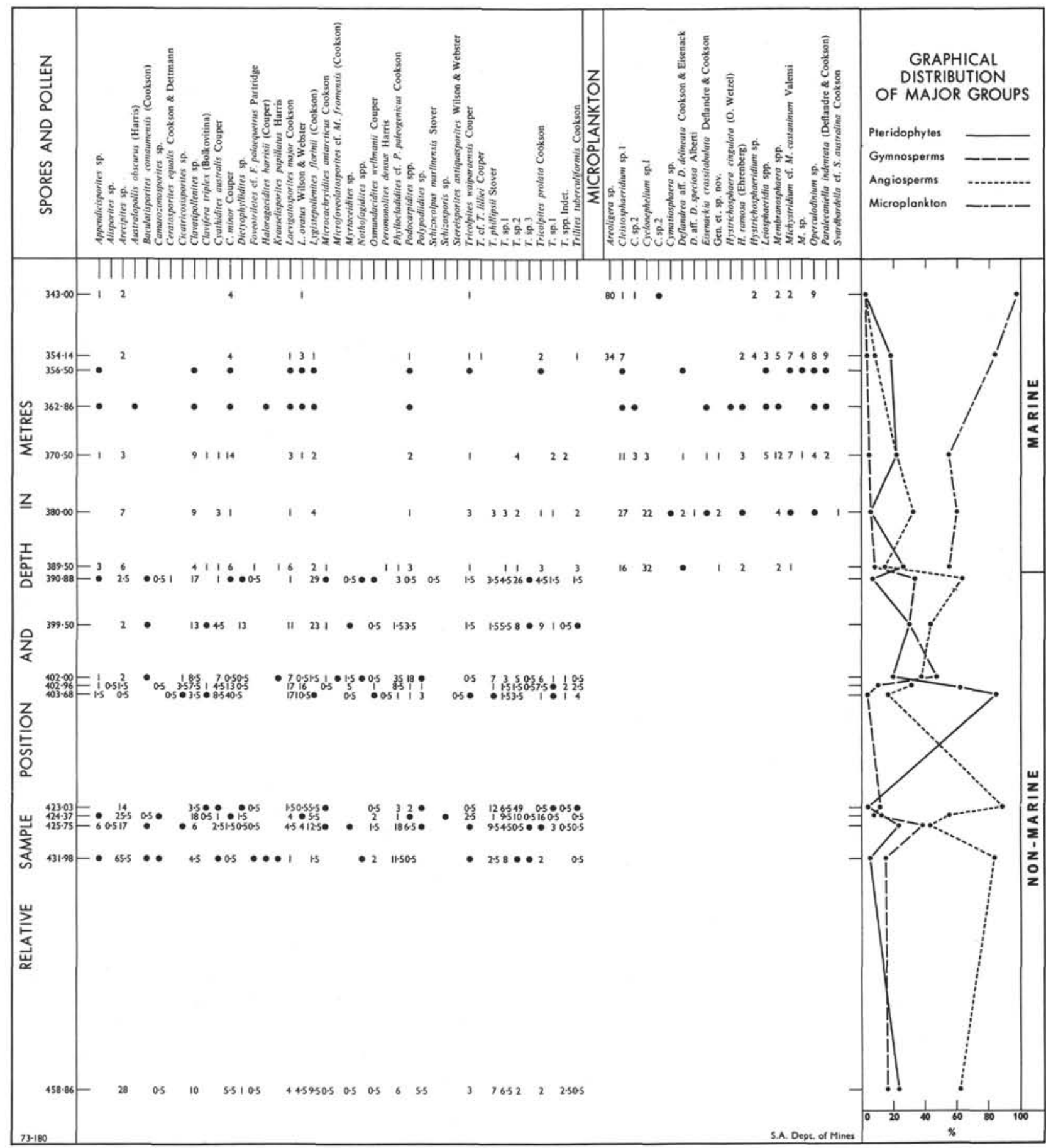

Figure 2. Species distribution chart and graphic representation of frequency changes of major plant groups. Species are recorded as percentages on individual counts of 200 specimens on samples from the volcanoclastic sequence and 100 speciemsn from samples within the marine sequence. $\bullet$ denotes species observed in the sample but not in the actual count.

Nothofagidites spp.: Nothofagidites Microflora (Dettman and Playford, 1968, 1969) and Nothofagidites senectus Zone (Stover and Partridge, in press), Late Cretaceous through Tertiary.

Peromonolites densus Harris: Lygistepollenites balmei Zone (middle Paleocene) through Miocene (Stover and Partridge, in press).
Schizocolpus marlinensis Stover: Gambierina edwardsii Zone (author's unpublished data) through Nothofagidites asperus Zone (late Eocene) (Stover and Partridge, in press).

Tricolpites waiparaensis Couper: ?Late Senonian to Maastrichtian in New Zealand (Couper, 1960) and Gambierina edwardsii Zone in southern Australia 
TABLE 1

Palynological Sample Data

\begin{tabular}{cccc}
\hline Core-Section & $\begin{array}{c}\text { Interval } \\
(\mathrm{cm})\end{array}$ & $\begin{array}{c}\text { Depth Below } \\
\text { Sea Floor } \\
(\mathrm{m})\end{array}$ & Sample No. \\
\hline $36-3$ & $108-110$ & 337.08 & $\mathrm{~S} 2504$ \\
$37-2$ & top & 343.00 & $\mathrm{~S} 2592$ \\
$38-2$ & $64-66$ & 354.14 & $\mathrm{~S} 2591$ \\
$38-4$ & top & 356.50 & $\mathrm{~S} 2590$ \\
$39-1$ & $136-138$ & 362.86 & $\mathrm{~S} 2589$ \\
$39, \mathrm{CC}$ & & 370.50 & $\mathrm{~S} 2588$ \\
$40, \mathrm{CC}$ & & 380.00 & $\mathrm{~S} 2587$ \\
$41, \mathrm{CC}$ & & 389.50 & $\mathrm{~S} 2496$ \\
$42-1$ & $88-92$ & 390.88 & $\mathrm{~S} 2493$ \\
$42, \mathrm{CC}$ & & 399.50 & $\mathrm{~S} 2497$ \\
$43, \mathrm{CC}$ & & 402.00 & $\mathrm{~S} 2498$ \\
$44-1$ & $46-48$ & 402.96 & $\mathrm{~S} 2500$ \\
$44-1$ & $118-120$ & 403.68 & $\mathrm{~S} 2501$ \\
$46-2$ & $103-106$ & 423.03 & $\mathrm{~S} 2502$ \\
$46-2$ & $137-140$ & 424.37 & $\mathrm{~S} 2503$ \\
$46-3$ & $125-128$ & 425.75 & $\mathrm{~S} 2492$ \\
$47-1$ & $98-100$ & 431.98 & $\mathrm{~S} 2505$ \\
$51-1$ & $136-138$ & 458.86 & $\mathrm{~S} 2494$ \\
$52-1$ & $130-132$ & 477.80 & $\mathrm{~S} 2506$ \\
$52-1$ & $135-137$ & 477.85 & $\mathrm{~S} 2507$ \\
$53-2$ & $62-63$ & 488.10 & $\mathrm{~S} 2499$ \\
$53-2$ & $64-65$ & 488.12 & $\mathrm{~S} 2495$ \\
\hline & & & \\
\hline
\end{tabular}

(author's unpublished data) Tricolpites longus to Lygistepollenites balmei Zone, Paleocene Gippsland Basin (Stover and Evans, in press).

Tricolpites phillipsii Stover: Lygistepollenites balmei Zone (Middle Paleocene) through Nothofagidites asperus Zone (Late Eocene) (Stover and Partridge, in press).

Eisenackia crassitabulata Deflandre and Cookson: Pebble Point Formation (Gambierina edwardsii Zone, middle Paleocene), Deflandre and Cookson (1955), Cookson and Eisenack (1965). Deflandre and Cookson's record of the species ("very rare") from the late Paleocene to early Eocene Princetown Member of the Dilwyn Clay, may be due to reworking.

Svardbardella australina Cookson: Haumurian (Maastrichtian), Campbell Island (wilson, 1968, 1972) to middle Paleocene, Pebble Point Formation (Cookson, 1965) (Gambierina edwardsii Zone, Harris 1965a, 1971), Cookson and Eisenack (1965).

With the exception of $T$. waiparaensis and $T$. phillipsii, the other species are very rare in this sequence and, apart from the microplankton, are derived from long distance wind transport.

Other species recorded from this sequence are either long ranging or endemic, and insufficient studies have been done on the remaining microplankton assemblage.

The evidence available, and despite the absence of characteristic index species of the southern Australian region, indicates a correlation with the Gambierina edwardsii Zone of Harris (1971) (= Lygistepollenites balmei Zone of Stover and Partridge in the Gippsland Basin). The type locality for this zone is in the Pebble Point Formation in the Otway Basin, and McGowran (1965) correlates a foraminiferal fauna with the Globorotalia pusilla pusilla Zone of Bolli (1957). The unit is therefore of middle Paleocene age (see also McGowran, 1968 and McGowran et al., 1971).

\section{ENVIRONMENTS OF DEPOSITION}

Carbonaceous sediments from Core 42 and below are derived from entirely nonmarine environments that range in part from paludal to lacustrine. The most significant change occurs in Core 41 with the sudden introduction of marine microplankton. In transgressive sequences elsewhere, and in particular in southern Australia, a transitional phase (marginal marine) is represented by low (less than 5\%) percentages of dinoflagellate cysts. The abundance increases with increasing marine influence (Harris, in press). There are two possible explanations for the sudden appearance of, and domination by, dinoflagellate cysts in this sequence. The first is that the core catcher sample comes from higher in the sequence which would mean that approximately 10 meters of section is missing and therefore not sampled. The other, and most likely, explanation is that the environment was rapidly inundated by the sea without a complex of marginal marine conditions developing. The dominance in the microplankton assemblage of Areoligera, Cleistosphaeridium, Cyclonephelium, and Operculodinium species suggests free access to the open marine environment although not necessarily deep water. The rapid decline in frequency of terrestrially derived palynomorphs supports this hypothesis and indicates a rapidly shrinking environment for the colonization of land plants.

\section{PHYTOGEOGRAPHIC NOTES}

The most striking attribute of this assemblage in comparison with other early Tertiary assemblages from the Southern Hemisphere is the complete lack of Proteacidites spp. Nevertheless the assemblage does have strong affinities with Late Cretaceous and early Tertiary microfloras from: southern Australia (Dettman and Playford, 1969; Harris, 1965a, 1971; Stover and Evans, in press; Stover and Partridge, in press), Queensland (Harris, 1965b, Hekel, 1972), New Zealand (Couper, 1960), Antarctica (Cranwell, 1959, 1969; Cranwell et al., 1960; McIntyre and Wilson, 1966; Wilson, 1967), southernmost South America (Cookson and Cranwell, 1967) and the younger (Miocene) lignites from the Kerguelan Islands (Cookson, 1947; Mechkova, 1969). Figure 3 indicates the distribution of these microfloras in the Southern Hemisphere.

Apart from the characteristically Australasian species listed previously in the discussion on biostratigraphy, Lygistepollenites florinii, Microcachryidites antarcticus, Myrtaceidites sp., Phyllocladidites $\mathrm{cf}$. P. paleogenicus, and Podocarpidites spp. are very strong Southern Hemisphere indicators, at least within the Late Cretaceous and early Tertiary. Although representatives of some of these may be found today in the pollen of species inhabiting the tropic zone and extending into the Northern Hemisphere, the meager fossil evidence suggests that genera, such as Phyllocladus and Podlocarpus, arrived in these regions late in the Tertiary (Muller, 1966). In contrast, the gymnosperm representatives in early Tertiary sediments from Sarawak, Malaysia and Pinus, Picea, and Tsuga, which are typically Asian and Northern Hemisphere genera (Muller, 1966, 1968). 


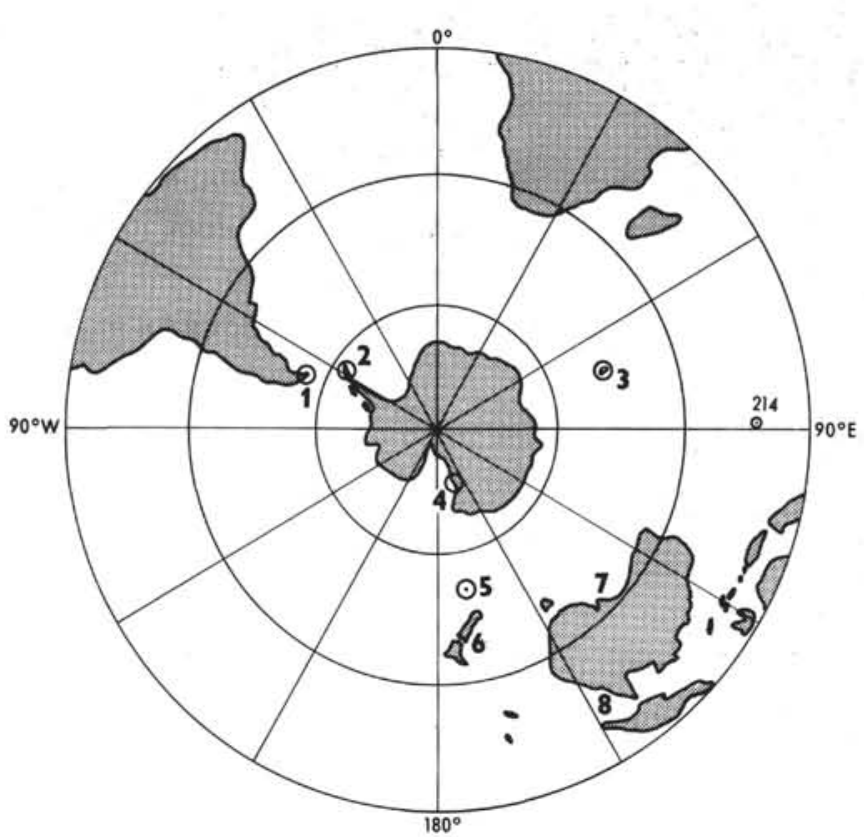

Figure 3. Distribution of known Late Cretaceous and early Tertiary microfloras in the Southern Hemisphere. Numbered localities refer to: 1, Southern Chile and Patagonia; 2, Seymour Island; 3, Kerguelen Islands; 4, McMurdo Sound; 5, Campbell Island; 6, New Zealand; 7, southern Australian basins; 8, Queensland basins.

Assemblages from tropical areas (Germeraad et al., 1968) and in Africa (Hoeken-Klinkenberg, 1964, 1966) Central America (Hammen, 1957, Hammen and Wymstra, 1964; Hammen and Garcia de Mutis, 1965; Leidelmeyer, 1966), India (Baksi, 1962, 1965; Ramanujam, 1966; Sah and Dutta, 1966) and Southeast Asia (Muller, 1968) bear little or no resemblance to the microfloras described here. USSR, northern Asia and North American microfloras are distinct also.

The flora at Site 214 is the result of colonization by plants capable of migration across oceanic waters (e.g., wind dispersed seeds) to a mid-oceanic island system. Although the elements of the flora indicate close relationships with those from Australasia, this does not imply contact or even closeness to the southern polar continents at this time. The obvious lack of Proteacidites spp. indicates that it is one group which evidently was not suited to this type of dispersal mechanism. The genus is widely distributed in the early Tertiary sediments of Australia, New Zealand, and southernmost South America. The Miocene microflora from Kerguelen is similar in that it has certain gymnosperms Phyllocladus, Podocarpus, and Microcachrys in common, but otherwise it has a distinctly younger aspect.

Climatic interpretation of palynological data is a dangerous procedure in early Tertiary sediments. Nevertheless, the presence of a microflora at Site 214 with abundant gymnosperm pollen of Dacrydium, Microcachrys, Phyllocladus, and Podocarpus together with elements similar to, or identical with, those from southern Australia and New Zealand coeval sediments points to a cool-to-warm temperate climate with a high rainfall. For example, the genus Ascarina, with pollen of two species indistinguishable from that of Clavatipollenites sp. (Plate 2, Fig. 12-14), is represented in New Zealand and the Kermadec Islands by A. lucida Hook. f. and A. lanceolata Hook. f. and is rare to common in New Zealand Paleocene to Recent sediments (Couper, 1960). No pollen descriptions of the other nine species of Ascarina, distributed throughout the Pacific islands of New Caledonia, the Philippines, the Society, Soloman, and Bismarck islands, are available. Kemp (1968) has discussed the affinities of Clavatipollenites and is cautious about its relationships with angiosperm pollen.

\section{CONCLUSIONS}

The microfloras from Site 214 have distinct Australasian affinities but are derived from a restricted phytogeographic province with no land connections to any of the present continents. Nevertheless, the assemblages correlate well with Paleocene (Late Cretaceous at the most) assemblages particularly from southern Australia. There is no evidence for similarity with other tropical early Tertiary microfloras from Africa, Central America, or Asia. Recent reconstructions involving part of Southeast Asia with Gondwanaland (Ridd, 1971; Audley-Charles et al., 1972) are neither supported by the palynological data presented here nor that from Australia.

\section{ACKNOWLEDGMENTS}

I am indebted to Dr. Brian McGowran who initiated this study and provided much of the necessary background information for Leg 22 and also discussed and criticized the ideas presented here. This paper is published with the permission of the Director of Mines.

\section{REFERENCES}

Audley-Charles, M. G., Cartser, D. J., and Milsom, J. S., 1972. Tectonic development of eastern Indonesia in relation to Gondwanaland dispersal: Nature Phys. Sci., v. 239 , p. 35-39.

Baksi, S. K., 1962. Palynological investigation of Simsang River tertiaries, South Shillong Front, Assam. Geol. Mining. Met. Soc. India Bull., v. 26, p. 1-22.

1965. Stratigraphy of Barail Series in southern part of Shillong Plateau, Assam, India: Am. Assoc. Petrol. Geol. Bull., v. 49, p. 2282-2288.

Belsky, C. Y., Boltenhagen, E., and Potonie, R., 1965. Sporae dispersal der Oberen Kreide von Gabun, Aequatoriales Afrika: Paleontol. Zh., v. 39, p. 72-83.

Bolli, H. M., 1957. The genera Globigerina and Globorotalia in the Paleocene-lower Eocene Lizard Springs Formation of Trinidad: U. S. Natl. Mus. Bull., v. 215, p. 61-82.

Cookson, I. C., 1947. Plant microfossils from the lignites of Kerguelen Archipelago: British Australian New Nealand Antarctic Res. Exped. Repts. Ser. A, 2, 127-142. 1965. Microplankton from the Paleocene Pebble Point Formation, south-western Victoria: Part 1. Roy Soc. Victoria Proc., v. 78, pl 137-141.

Cookson, I. C. and Cranwell, L. M., 1967. Lower Tertiary microplankton, spores and pollen grains from southernmost Chile: Micropaleontology, v. 13, p. 204-216.

Cookson, I. C. and Eisenack, A., 1965. Microplankton from the Paleocene Pebble Point Formation, southwestern Victoria (Pt. 2): Roy. Soc. Victoria Proc., v. 79, p. 139-146. 
Couper, R. A., 1960. New Zealand Mesozoic and Cainozoic plant microfossils: New Zealand Geol. Surv. Paleont. Bull., 32.

Cranwell, L. M., 1959. Fossil pollen from Seymour Island, Antarctica: Nature, v. 184, p. 1782-1785.

- 1969. Palynological intimations of some pre-Oligocene antarctic climates, F.M. van zinderen Bakker (Ed.): Palaeoecol. Africa, v. 5, p. 1-19.

Cranwell, L. M., Harrington, H. J., and Speden, I. G., 1960. Lower Tertiary microfossils from McMurdo Sound, Antarctica: Nature, v. 186, p. 700-702.

Deflandre, G. and Cookson, I. C., 1955. Fossil microplankton from Australian Late Mesozoic and Tertiary sediments: Austral. J. Mar. Freshw. Res., v. 6, p. 242-313.

Dettmann, M. E. and Playford, G., 1968. Taxonomy of some Cretaceous spores and pollen grains from eastern Australia: Roy. Soc. Victoria Proc., v. 81, p. 69-93. 1969. Palynology of the Australian Cretaceous-a review. In Stratigraphy and Palaeontology: Essays in honor of Dorothy Hill, Campbell, K. S. W. (Ed.): Canberra (A.N.U. Press).

Germeraad, J. H., Hopping, C. A., and Muller, J., 1968. Palynology of Tertiary sediments of tropical areas: Rev. Palaeobot. Palynol., v. 6, p. 189-348.

Hammen, T., van der, 1957. Climatic periodicity and evolution of South American Maestrichtian and Tertiary floras: Bol. Geol. Bogota, v. 5, p. 53-9.

Hammen, T., van der, and Garcia de Mutis, C., 1965. The Paleocene flora of Colombia: Leidse Geol. Meded., v. 38, p. $37-48$.

Hammen, T., van der, and Wymstra, T. A., 1964. A palynological study of the Tertiary and Upper Cretaceous of British Guiana: Leidse Geol. Meded., v. 30, p. 183-241.

Harris, W. K., 1965a. Basal Tertiary microfloras from the Princetown area, Victoria: Palaeontographica B, v. 115, p. 75-106

, 1965b. Tertiary microfloras from Brisbane, Queensland: Geol. Surv. Queensland Rept., v. 10. 1971. Tertiary stratigraphic palynology, Otway Basin. In The Otway Basin of south east Australia: Geol. Survs. S. Austral. Vict. Spec. Bull., p. 67-87.

in press. Tertiary non-marine dinoflagellate cyst assemblages from Australia: Geol. Soc. Austral. Spec. Publ., 4.

Hekel, H., 1972. Pollen and spore assemblages from Queensland Tertiary sediments: Geol. Surv. Queensland Publ., v. 355.

Hoeken-Klinkenberg, P. J.M. van, 1964. A palynological investigation of some Upper Cretaceous sediments in Nigeria: Pollen Spores, v. 6, p. 209-231.

1966. Maastrichtian, Paleocene and Eocene pollen and spores from Nigeria: Leidse Geol. Meded., v. 38 , p. $37-48$.

Kemp, E. M., 1968. Probable angiosperm pollen from the British Barremian to Albian strata: Palaeontology, v. 11, p. 421-434.

Leidelmeyer, P., 1966. The Paleocene and Lower Eocene pollen flora of Guyana: Leidse Geol. Meded., v. 38, p. 49-70.
McGowran, B., 1965. Two Paleocene foraminiferal faunas from the Wangerrip Group, Pebble Point coastal section, Victoria: Roy. Soc. Victoria Proc., v. 79, p. 9-74.

1968. Late Cretaceous and early Tertiary correlations in the Indo-Pacific region: Geol. Soc. India, Memoir, 2, p. 335-360.

McGowran, B., Lindsay, J. M., and Harris, W. K., 1971. Attempted reconciliation of Tertiary biostratigraphic systems, Otway Basin. In The Otway Basin of southeast Australia: Geol. Survs. S. Austral. Victoria Spec. Bull., p. 273-281.

McIntyre, D. J. and Wilson, G. J., 1966. Preliminary palynology of some Antarctic Tertiary erratics: New Zealand J. Bot., v. 4, p. 315-321.

McKenzie, D., and Sclater, J. G., 1971. The evolution of the Indian Ocean since the Late Cretaceous: Roy. Astr. Soc. Geophys. J., v. 25, p. 437-528.

Mechkova, J. I., 1969. Pollens et spores des Lignites des Iles Kerguelen: Terres Austral. Antarctica fr., Paris, v. 46, p. 11-21.

Muller, J., 1966. Montane pollen from the Tertiary of N.W. Borneo: Blumea, v. 14, p. 231-235.

1968. Palynology of the Pedawan and Plateau Sandstone Formations (Cretaceous-Eocene) in Sarawak, Malaysia: Micropaleontology, v. 14, p. 1-37.

Norton, N. J. and Hall, J. W., 1967. Guide sporomorphae in the Upper Cretaceous-lower Tertiary of eastern Montana (U.S.A.): Rev. Palaeobot. Palynol., v. 2, p. 99-110.

Ramanujam, C. G. K., 1966. Palynology of the Miocene lignite from South Arcot District, Madras, India: Pollen Spores, v. 8, p. 149-203.

Ridd, M. F., 1971. Southeast Asia as part of Gondwanaland: Nature, v. 234, p. 531-533.

Sah, S. C. D. and Dutta, S. K., 1966. Palyno-stratigraphy of the sedimentary formations of Assam: Pt. 1. Stratigraphical position of the Cherra Formation: Palaeobotanist, v. 15, p. 72-86.

Straka, H., 1966. Palynologia Madagassica et Mascarenica. Fam. 50-59 bis: Pollen Spores, v. 8, p. 241-264.

Srivastava, S. K., 1966. Upper Cretaceous microflora (Maestrichtian) from Scollard, Alberta, Canada: Pollen Spores, v. 8, p. 497-522.

Stover, L. E. and Evans, P. R., in press. Upper Cretaceous-Eocene spore-pollen zonation offshore Gippsland Basin, Australia: Geol. Soc. Austral. Spec. Publ., v. 4.

Stover, L. E. and Partridge, in press. Tertiary and Late Cretaceous spores and pollen from the Gippsland Basin, southeastern Australia: Roy. Soc. Victoria Proc.

Wilson, G. J., 1967. Some new species of lower Tertiary dinoflagellates from McMurdo Sound, Antarctica: New Zealand J. Bot., v. 5, p. 57-83.

1968. Microplankton from the Garden Cove Formation, Campbell Island: New Zealand J. Bot., v. 5, p. $223-40$.

1972. Age of the Garden Cove Formation, Campbell Island. New Zealand J. Geol. Geophys., v. 15, p. 184-185. 



\section{EXPLANATION TO PLATES}

All figures $\times 750$ and in bright field unless otherwise specified. NDC refers to Nomarski differential interference contrast

\section{PLATE 1}

Figure 1 Laevigatosporites major Cookson. S2053/, 37.5 : 108.5. Gradational forms between this species and $L$. ovatus Wilson and Webster make separation of the two species difficult.

Figure $2 \quad$ Polypodiidites sp. S2498/2, $28.1: 108.8$.

Figures 3,4 Microfoveolatosporites cf. M. fromensis (Cookson) Harris. S2498/1, $33.5: 101.8 ; 35.5: 96.5$.

Figure 5

Peromonolites densus Harris. S2501/1, 42.2 : 109.3.

Figure 6

Baculatisporites comaumensis (Cookson), $\times 500$. S2498/2, $28.1: 110.8$.

Figure 7

Osmundacidites wellmanii Couper. S2492/1, 34.5 : 103.9 .

Figure 8

Dictyophyllidites sp. S2502/1, 32.9 : 97.4 .

Figure 9

Cyathidites australis Couper. S2503/1, 42.9 : 102.8. This species appear to intergrade with $C$. minor Couper.

Figure 10 Clavifera triplex (Bolkovitina). S2053/1, 30.6 : 109.5 .

Figure 11 Stereisporites antiquasporites Wilson and Webster. S2501/1, 40.3 : 96.9 .

Figure 12 Foveotriletes cf. Partridge. S2498/2,31.9:109.9.

Figure 13 Trilites tuberculiformis Cookson. S2501/1, 50.7 : 95.7.

Figure 14 Ceratosporites equalis Cookson and Dettmann. S2503/1, 39.2: 105.9 .

Figure $15 \quad$ Krauselisporites papillatus Harris. S2498/2, 26.8 : 107.9 .

Figure $16 \quad$ Camarozonosporites sp. S2503/1, $41.1: 109.3$.

Figure 17 Appendicisporites sp. S2498/1, $40.6: 101.8$.

Figure $18 \quad$ Cicatricosisporites sp. S2498/1, 38.7 : 98.3 . 
PLATE 1
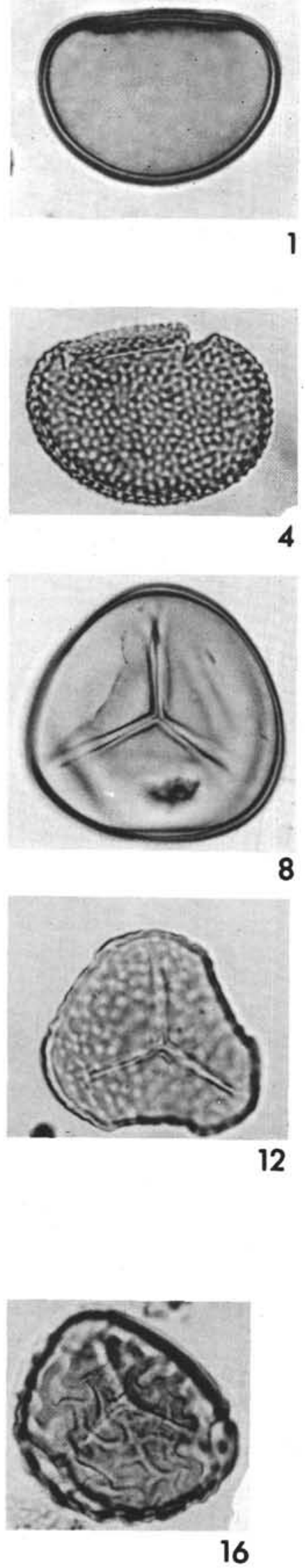

8
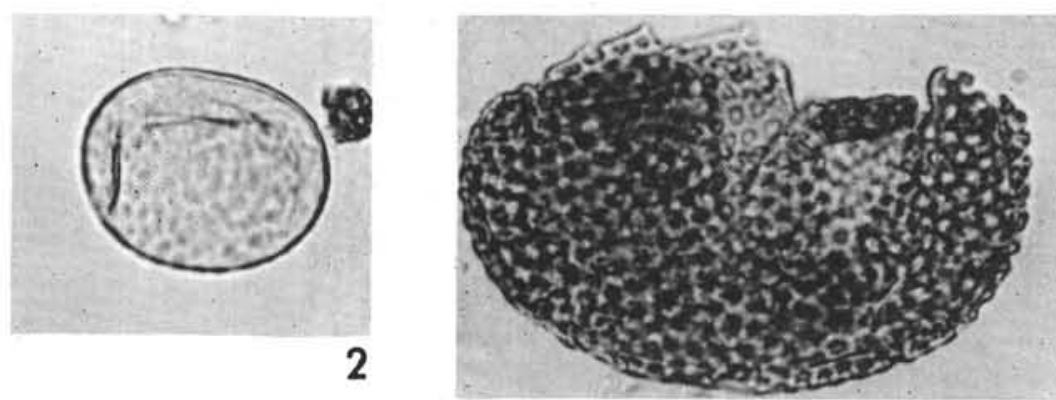

3
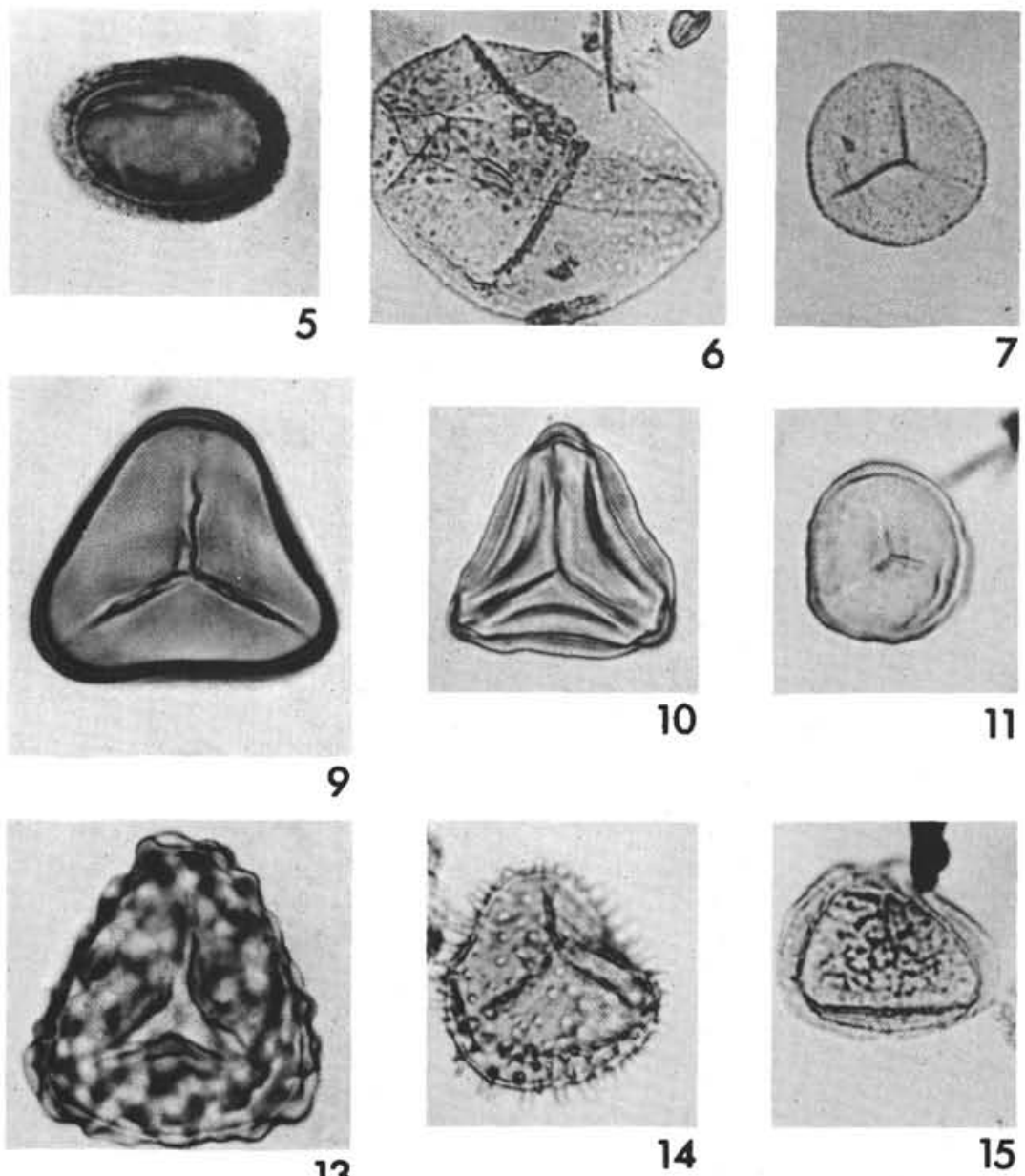

13
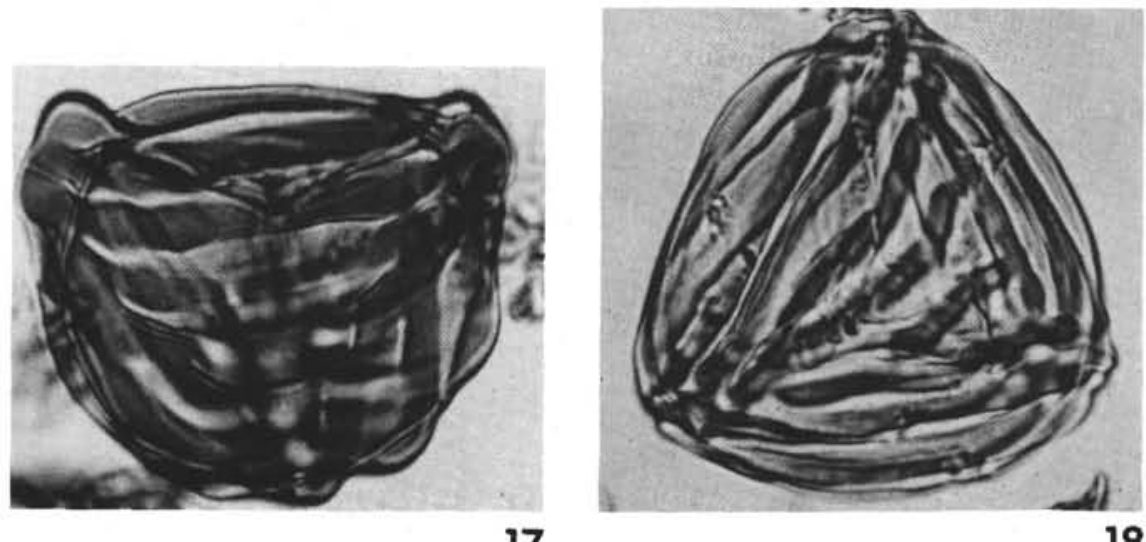

17 
PLATE 2

Figures 1,2 Schizosporis spp. S2503/1, 40.7 : 94.0; S2498/1, 34.1 : 95.5 . Figure 1 is similar to a species occurring rarely in southeastern Australian Paleocene sediments and to Ovoidites ligneolus Potonié.

Figures 3, 4 Lygistepollenites florinii (Cookson). S2493/1, 41.6 : 109.5; S2503/1, 40.8: 110.1. These specimens demonstrate the range of variability accepted in the species.

Figures 5, $6 \quad$ Podocarpidites spp. S2498/2, 25.7 : 105.4; S2492/1, $24.2: 107.4$. Figure 5 is closely similar to $P$. ellipticus Cookson.

Figure 7 Microcachryidites antarcticus Cookson. S2497/1, 26.5 : 105.6 .

Figures 8,9 "Phyllocladidites" cf. "P." Paleogenicus Cookson, $\mathrm{X}$ 1250. S2498/2, 38.8 : 111.1. Figure 8-NDC, Figure 9-Phase contrast.

Figures 10,11 Arecipites sp. X1250. S2498/2, 43.6 : 93.6. Figure 11-Phase contrast.

Figures 12,13, Clavatipollenites sp.; Figures. 12 and 13, X 1250. $14 \quad \mathrm{~S} 2493 / 1,44.3: 96.6 ; \mathrm{S} 2497 / 1,39.2: 109.5$. Figure 13-NDC Figure 14 is an uncommon trichotomosulcate form.

Figure 15 Haloragacidites harrisii (Couper) Harris. S2589/1, $35.7: 103.9$.

Figure $16 \quad$ Tricolpites sp. 3. S2493/1, $36.0: 109.3$.

Figures 17, 18 Tricolpites sp. 1, X 1250. S2492/1, 38.9 : 106.2; S2498/2, 35.1: 111.0 . Figure 18 by NDC.

Figure $19 T$. waiparaensis Couper, $\times$ 1250. S2503/1, 43.3 : 92.9. Phase contrast. This species is similar to $T$. reticulata Cookson and T. microreticulata Belsky, Boltenhagen and Potonié. T. interangulas Newman is also similar. With the exception of $T$. reticulata (Miocene, Kerguelen) the other species are characteristic Late Cretaceous species in equatorial Africa (Belsky, Boltenhagen \& Potonié, 1965), Alberta, Canada (Srivastava, 1966) and Montana, U.S.A. (Norton and Hall, 1967). 
Plate 2
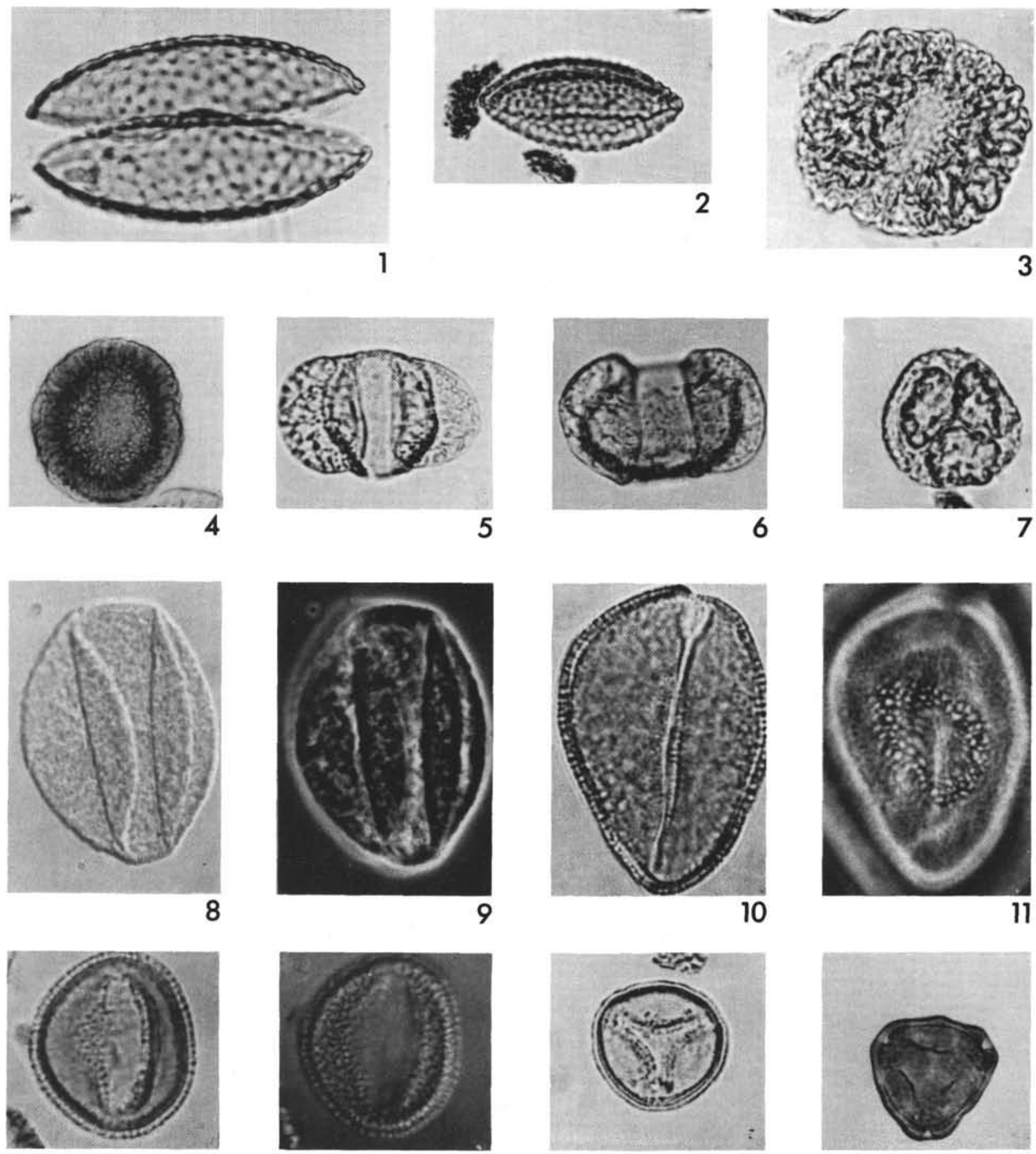

12

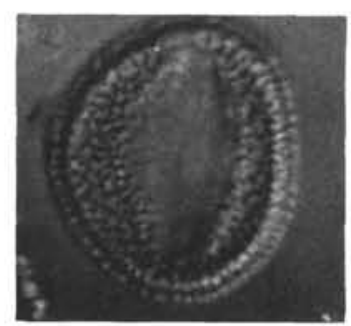

13

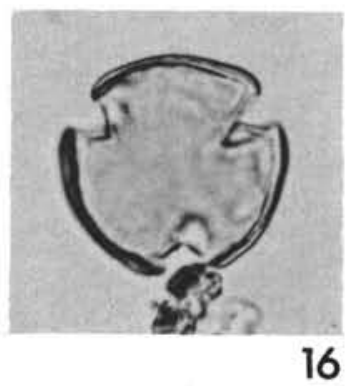

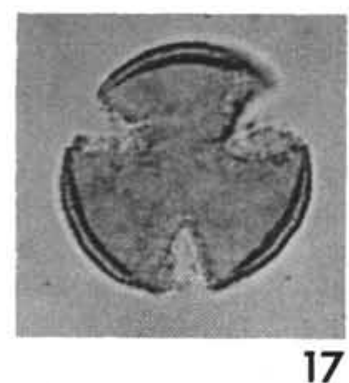
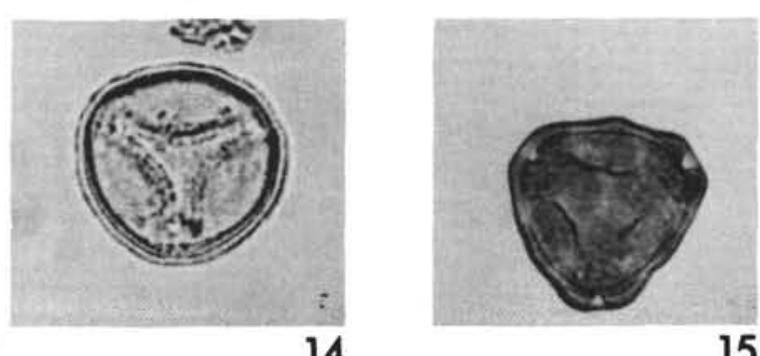

15

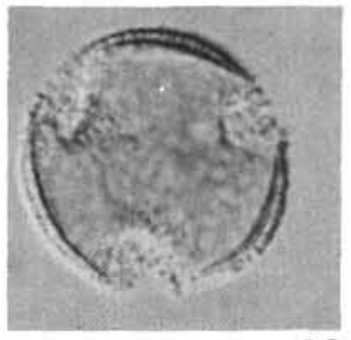

18

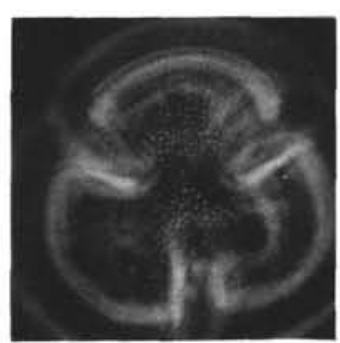

19 


\section{PLATE 3}

Figure 1

$T$. waiparaensis Couper.

Figure 2

T. phillipsii Stover, X 1250. S2502/1, $35.5: 102.2$. By NDC.

Figure 3

Tricolpites sp. $2, \times 1250 . \mathrm{S} 2502 / 2,38.5: 96.9$. This species may only be a prolate form of $T$. sp. 1 .

Figures 4, $5 \quad$ Myrtaceidites sp., X 1250. S2498/2, 36.1: 107.9 . Figure 4 by Phase Contrast.

Figures 6, $7 \quad$ Tricolpites $\mathrm{cf}$. T. lilliei Couper. S2591/1, 31.0 : 96.0. Mid and high focus. The ornament is similar to $T$. lilliei but the apertures appear to be more complex.

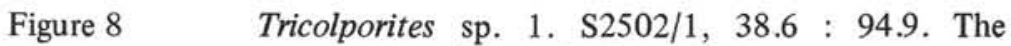
ornament on this species is spinulate.

Figures 9, 10 Tricolporites prolata Cookson, X 1250. S2502/2, $45.6: 101.6$. Mid and high focus.

Figure 11 Australopollis obscurus (Harris) Krutzsch. S2589/2, $36.8: 111.0$. Grain is fractured.

Figures 12, 13, Nothofagidites spp. S2493/1, 36.6 : 94.4; S2587/4, $14 \quad 41.0: 101.7 ; \mathrm{S} 2505 / 2,41.8: 100.3$. Figures 12 and 13 are of the $N$. emarcida- $N$. hetera complex and Figure 14 is of the $N$. brachyspinulosa type.

Figure 15 Schizocolpus marlinensis Stover, X 1250. S2503/1, $29.8: 109.0$. This species very closely resembles the pollen of the Madagascan genus Didymeles (Straka, 1966; Stover and Evans, 1973).

Figure $16 \quad$ Leiosphaeridia sp. S2589/2, $31.2: 106.6$.

Figures 17, 18 Paralecaniella indentata (Deflandre and Cookson). S2590/1, 36.2 : 103.2; 41.9 : 99.0. Phase contrast. Note the girdle-like groove in Figure 18.

Figures 19, 20 Michystridium sp. S2590/2, 30.6 : 109.1. Figure 20 by Phase Contrast. Ornament consists of evenly spaced very short rods.

Figure $21 \quad$ Cymatiosphaera sp., $\times 1250$. S2587/1, $40.8: 104.0$. Phase contrast. This species is similar to $C$. eupelos (Valensi) Deflandre.

Figure 22 Michystridium cf. M. castaninum Valensi. S2588/2, $25.9: 105.2$.

Figure 23 ?Pterospermopsis sp. S2587/4, 42.2 : 106.6. Only one specimen of this species has been found. 
PLATE 3
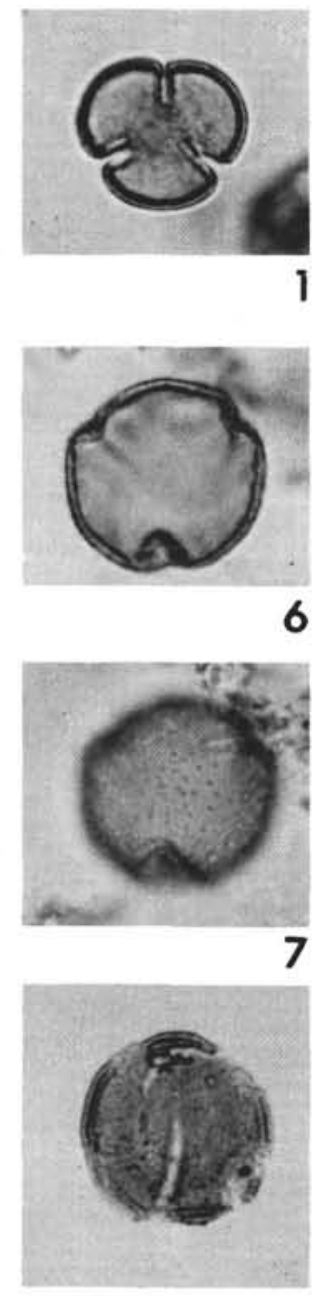

11
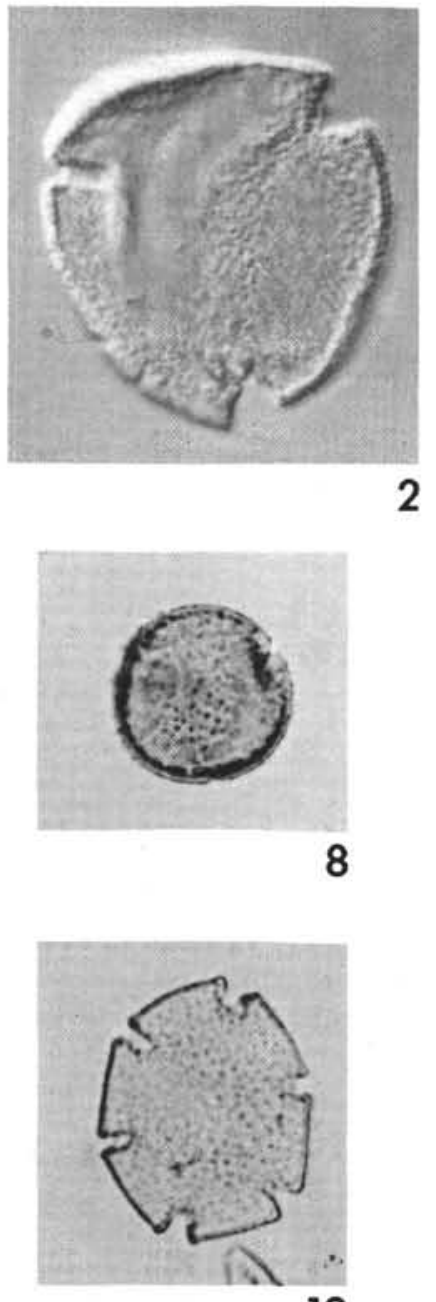

12
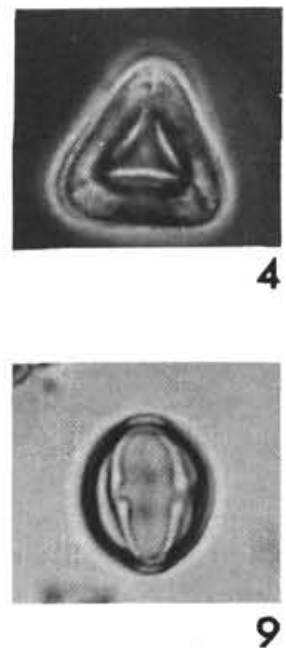

9

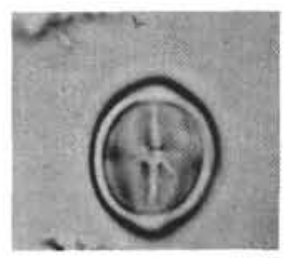

10

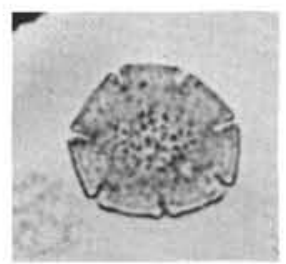

13
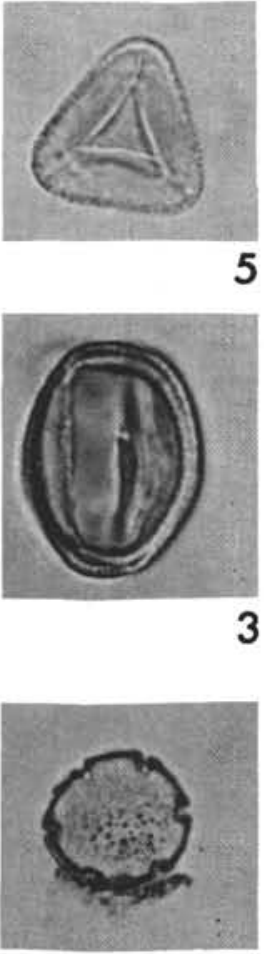

14

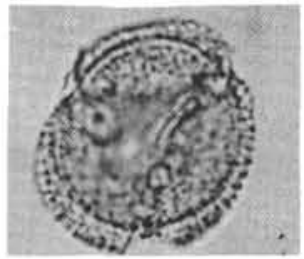

15

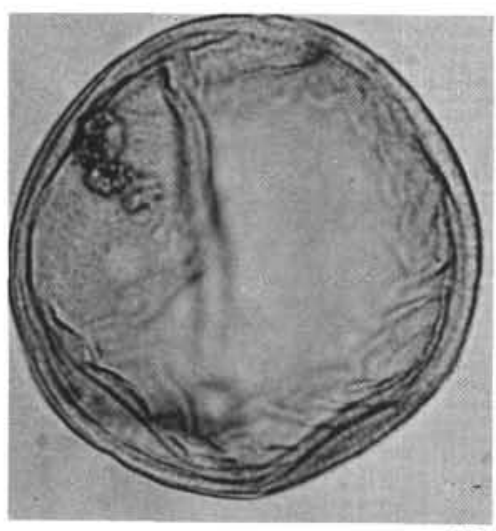

16
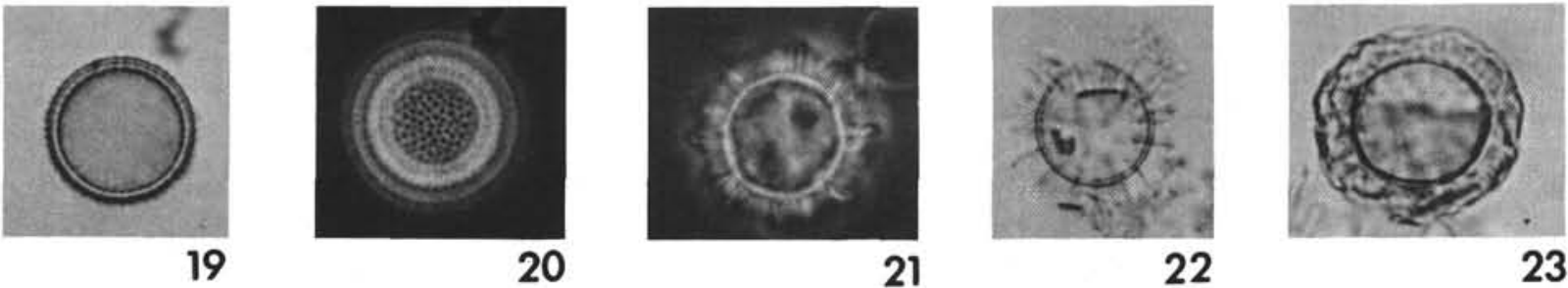

21

22

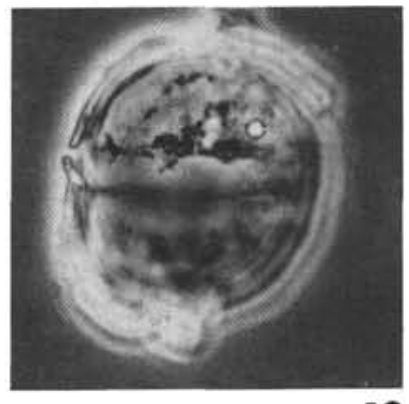

18 


\section{PLATE 4}

Figures 1,2 Deflandrea aff. D. delineata Cookson and Eisenack. S2590/2, $22.6: 98.0$. Figure 2 section of capsule in Phase Contrast. Note the foveolute sculpture pattern. This pattern is also present on the periphragm.

Figure 3

D. aff. D. speciosa Alberti. S2587/4, $24.2: 109.8$.

Figure 4

Svardbardella cf. S. australina Cookson, $\times 500$. S2587/1, $27.1: 97.1$. Phase contrast.

Figures 5, $6 \quad$ Membranosphaera sp. S2587/4, 32.1: 95.7. Phase contrast.

Figures 7-11 Gen. and sp. nov. Figures 7-9, S2587/4, 35.5 : 103.8 . High mid and low focus. Figures 10 and 11, S2587/4, 32.1 : 95.7. Figure 11, phase contrast.

Figures 12,13 Cleistosphaeridium sp. 2, mid and high focus. Figures $1412,13, \mathrm{~S} 2590 / 2,23.2: 112.2$, Figure 14, S2588/1, $40.8: 108.7$.

Figure 15 Hystrichosphaera ramosa (Ehrenberg), $\times 500$. S2587/1, 42.6 : 95.1. Phase contrast.

Figure 16 Cleistosphaeridium sp. 1, X 500. S2587/4, 42.2 : 104.7. Phase contrast. 
PLATE 4
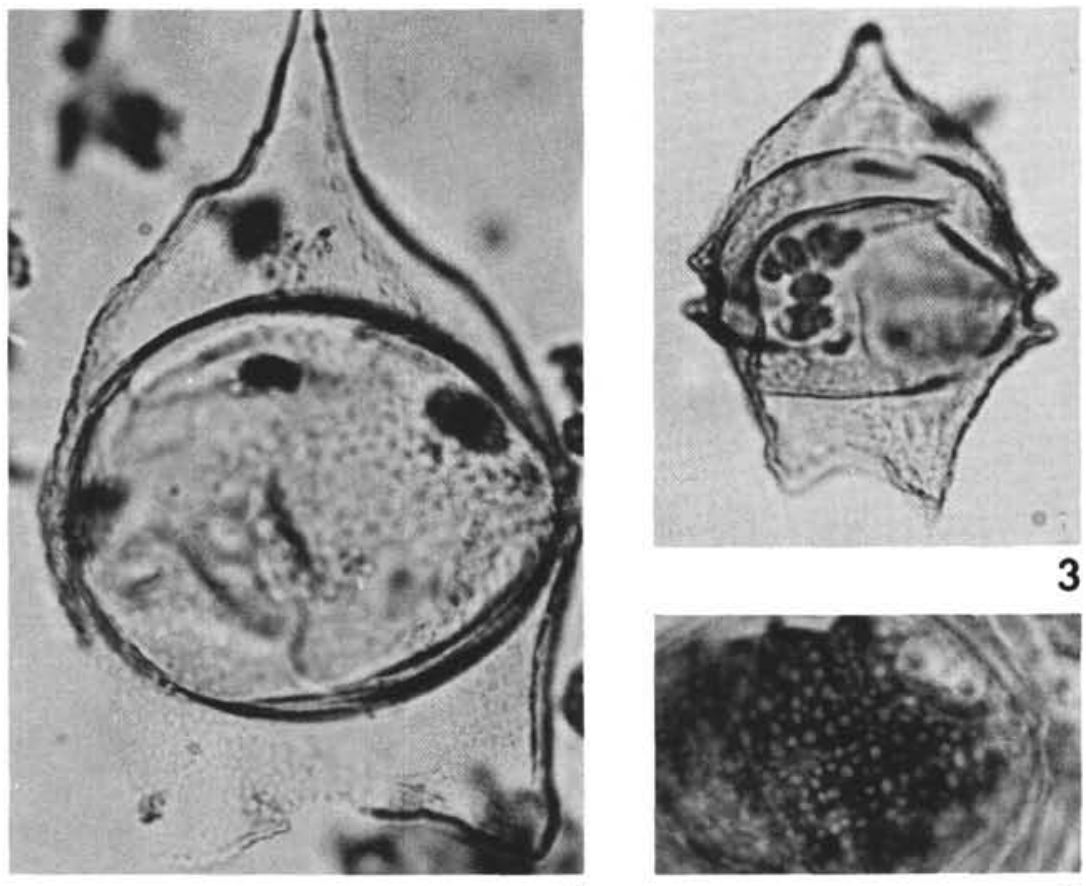

3

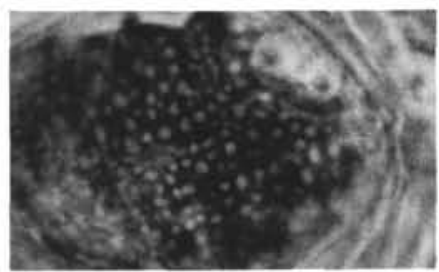

2

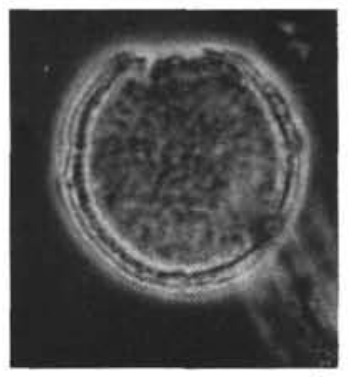

5
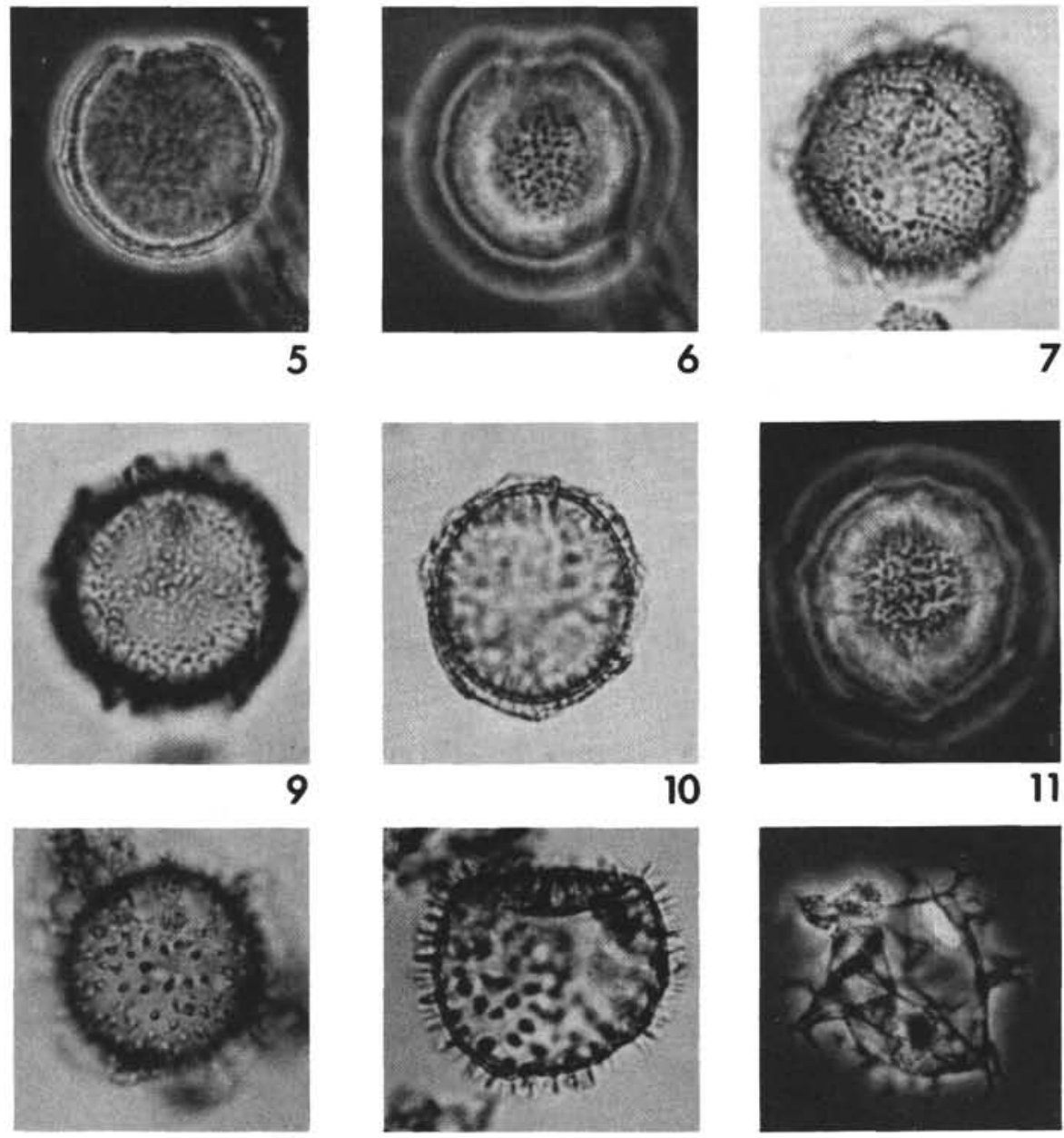

13
10
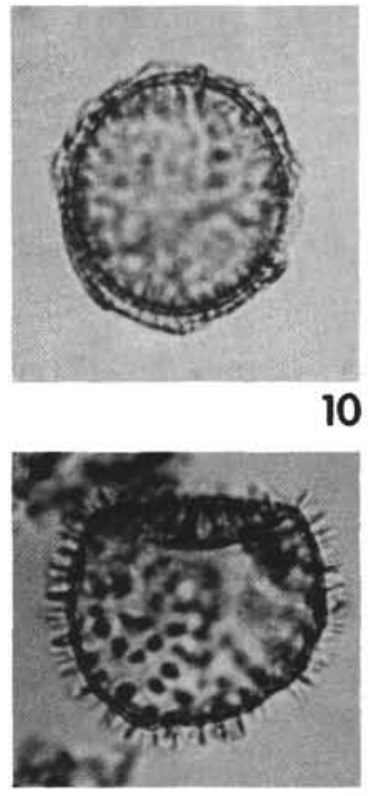

14

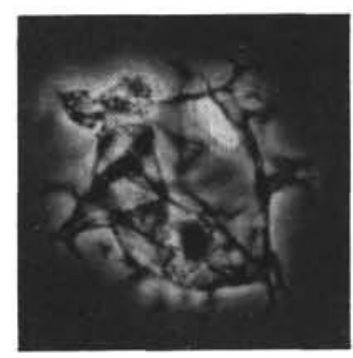

15
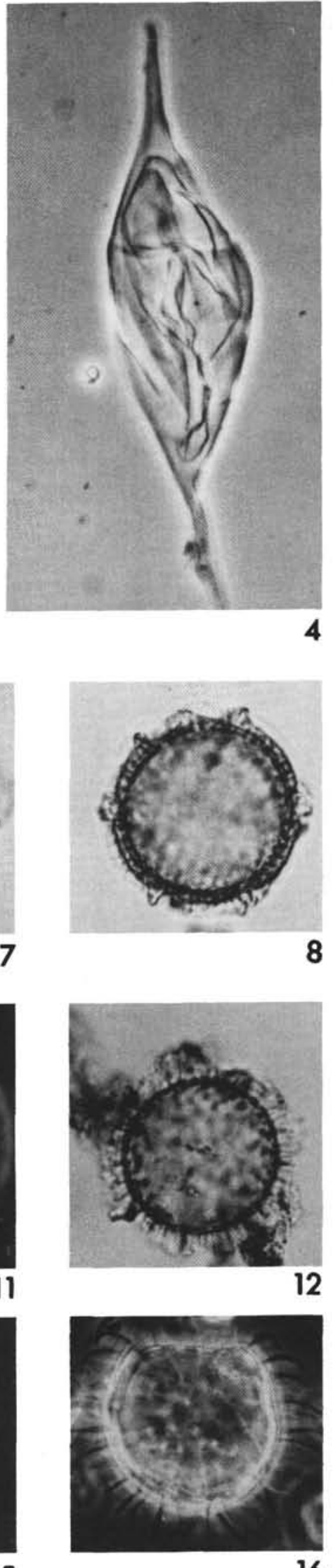

16 


\section{PLATE 5}

Figures 1,2 Operculodinium sp. S2589/1, $32.5: 108.1$. High and mid focus.

Figure $3 \quad$ Hystrichosphaeridium sp. S2589/1, 29.7 : 112.1.

Figure $4 \quad$ Cleistosphaeridium sp.

Figure $5 \quad$ Cyclonephelium sp. 2 S2592/2, $35.9: 109.8$.

Figure $6 \quad$ Cyclonephelium sp. 1, X 500. S2587/4, 25.7: 109.8 .

Figure $7 \quad$ Areoligera sp. S2592/2, 31.1 : 109.6.

Figures 8,9 Cleistosphaeridium sp., $\times$ 500. S2587/1, 24.2 : 95.6; $25.6: 113.1$. Phase contrast. 


\section{PLATE 5}
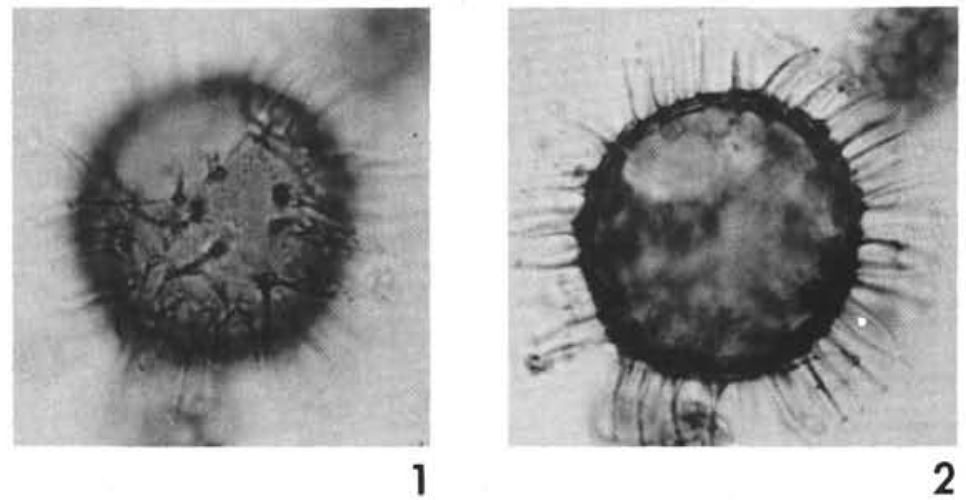

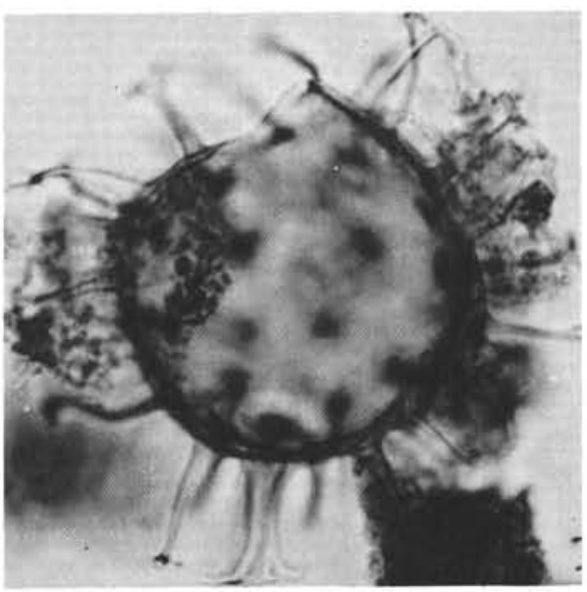

3
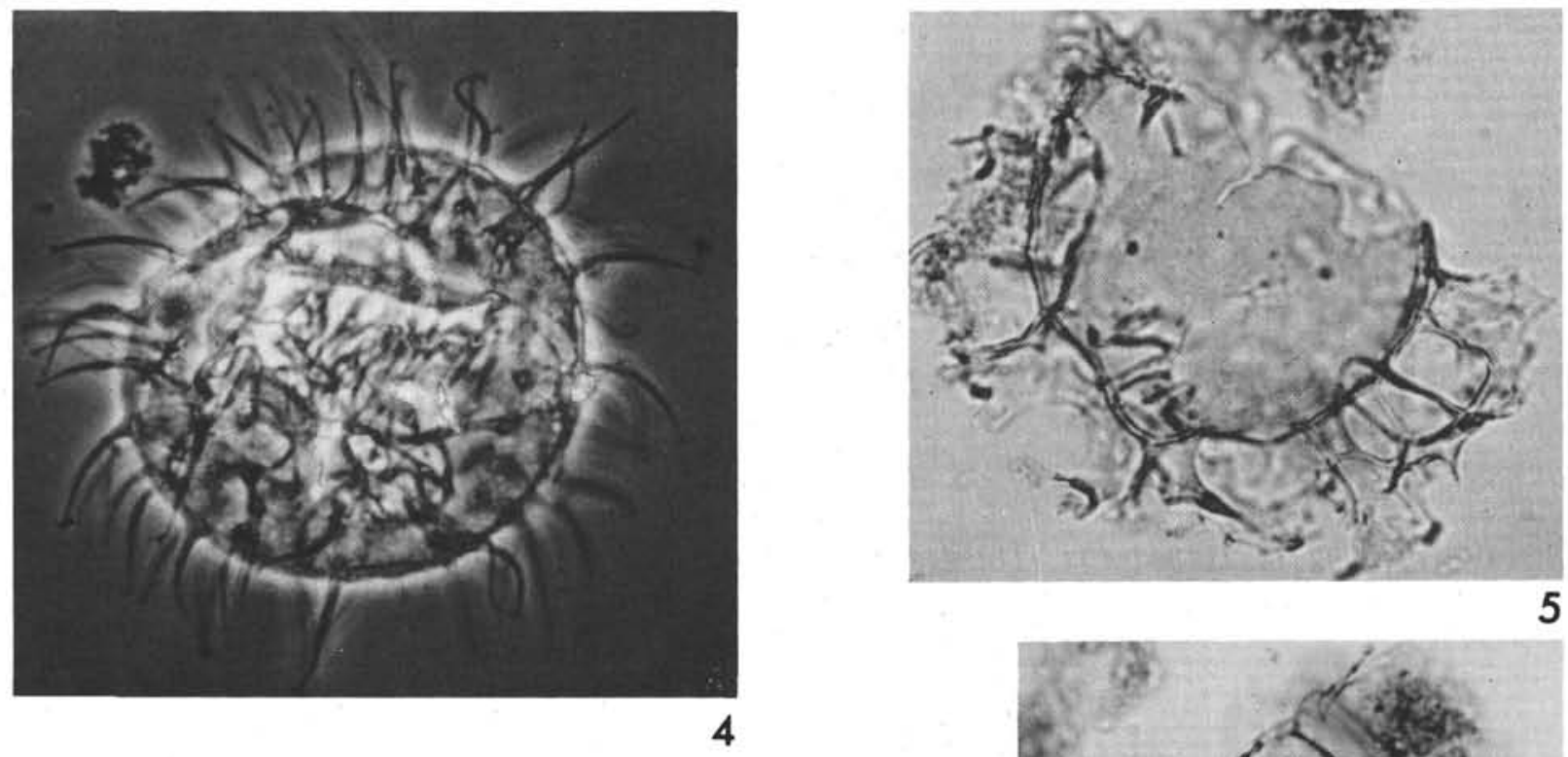

4
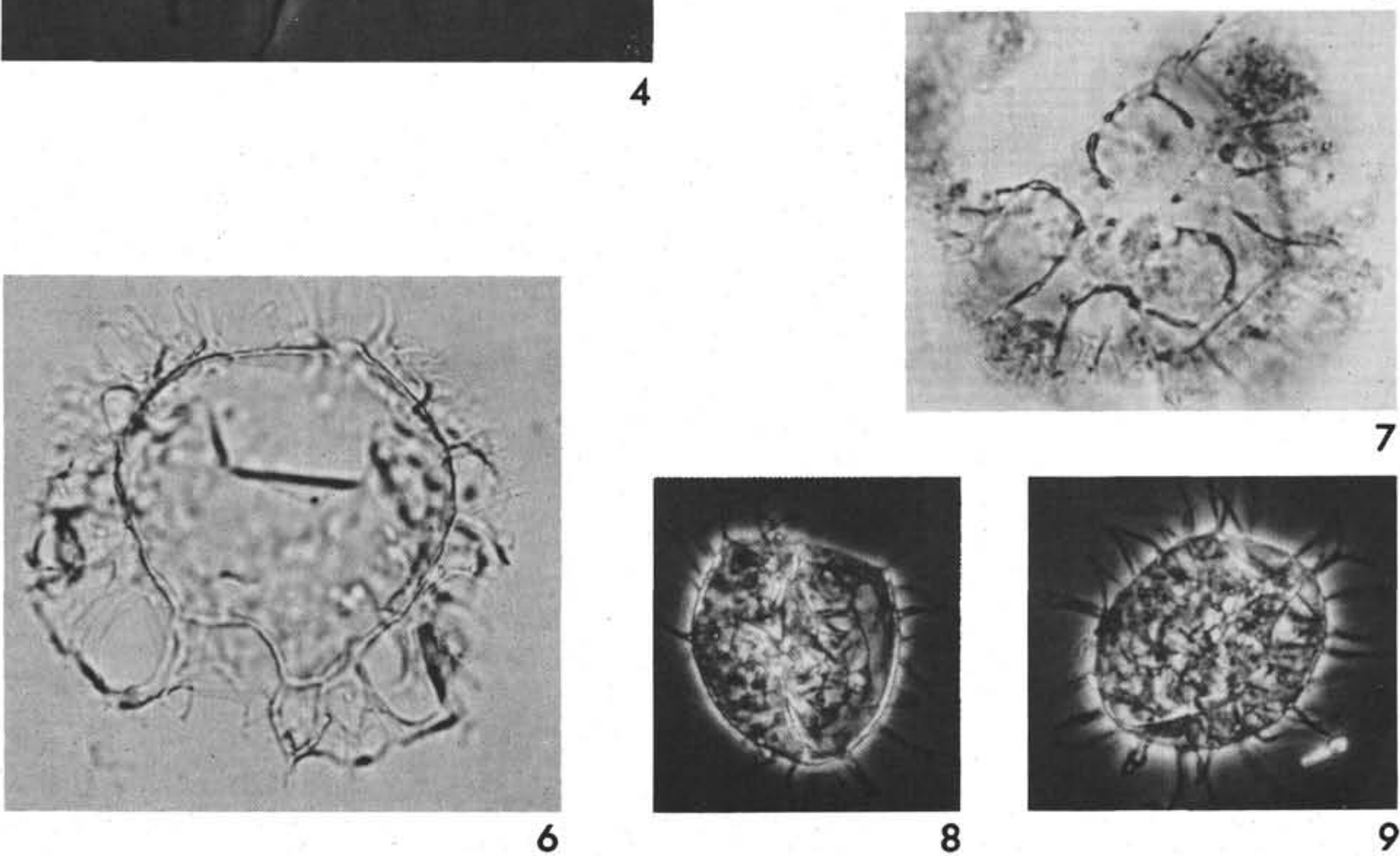